IZA DP No. 8056

Do School Budgets Matter? The Effect of Budget Referenda on Student Performance

Kyung-Gon Lee

Solomon W. Polachek

March 2014 


\title{
Do School Budgets Matter? The Effect of Budget Referenda on Student Performance
}

\author{
Kyung-Gon Lee \\ Korean Labor Institute \\ and Sungshin Women's University \\ Solomon W. Polachek \\ State University of New York at Binghamton \\ and IZA
}

Discussion Paper No. 8056

March 2014

IZA

P.O. Box 7240

53072 Bonn

Germany

\author{
Phone: +49-228-3894-0 \\ Fax: +49-228-3894-180 \\ E-mail: iza@iza.org
}

\begin{abstract}
Any opinions expressed here are those of the author(s) and not those of IZA. Research published in this series may include views on policy, but the institute itself takes no institutional policy positions. The IZA research network is committed to the IZA Guiding Principles of Research Integrity.

The Institute for the Study of Labor (IZA) in Bonn is a local and virtual international research center and a place of communication between science, politics and business. IZA is an independent nonprofit organization supported by Deutsche Post Foundation. The center is associated with the University of Bonn and offers a stimulating research environment through its international network, workshops and conferences, data service, project support, research visits and doctoral program. IZA engages in (i) original and internationally competitive research in all fields of labor economics, (ii) development of policy concepts, and (iii) dissemination of research results and concepts to the interested public.
\end{abstract}

IZA Discussion Papers often represent preliminary work and are circulated to encourage discussion. Citation of such a paper should account for its provisional character. A revised version may be available directly from the author. 


\section{ABSTRACT \\ Do School Budgets Matter? The Effect of Budget Referenda on Student Performance}

This paper analyzes how changes in school expenditures affect dropout rates and standardized test scores based on data from 465 school districts in New York during the $2003 / 04$ to the 2008/09 school years. Past traditional regression approaches show inconsistent results of school expenditures because of an endogeneity problem. The regression discontinuity design used in this study isolates exogenous variation in school expenditures per pupil by comparing school districts where budget referenda passed and failed by narrow margins. The results indicate that increases in school expenditures reduce dropout rates but have limited effects on student test scores.

JEL Classification: $\quad 120,121,122$

Keywords: educational expenditures, school budget referenda, school dropout rates, student performance

Corresponding author:

Solomon W. Polachek

Department of Economics

State University of New York at Binghamton

Binghamton, NY 13902-6000

USA

E-mail: polachek@binghamton.edu

\footnotetext{
* The authors thank Carmen Carrion-Flores, Ronald Ehrenberg, Alfonso Flores-Lagunes, and David Slusky for valuable comments.
} 


\section{Introduction}

The question of how school resources relate to school performance has remained a controversial issue for more than 45 years since the Coleman report was first published in 1966. One expects that greater school expenditures result in decreasing class size, hiring better teachers, and procuring other inputs to increase overall school quality, so that students achieve more academic success. However, in influential papers, Hanushek (1986, 1989, 1997) concluded that the studies he assembled did not provide evidence of a consistent relation between school expenditures and school performance. Hanushek (1986) utilized data from 33 different articles and books. These comprised a total of 147 pertinent studies, and focused on five school inputs. ${ }^{1}$ Based on these, Hanushek classified school inputs and student/school performance relationships into one of four categories based on regression coefficient signs and statistical significant. He found a very low percent of studies yielded positive and significant effects. ${ }^{2}$ As a result of this research, a prevailing consensus emerged of no strong systematic relationship between school spending and school performance. ${ }^{3}$ However, a number of research papers have begun to challenge this conclusion.

These latter studies argue that school resources are actually positively associated with educational achievement. For example, Krueger (2003) criticizes Hanushek's research method as based on studies that contain numerous estimates from small subsamples of the same data, and which are tallied separately within each publication. When counting each publication as a single study, he finds that the effect of school resources on achievement to be more positive. Hedges et al. (1994a, b) implement a meta-analysis. They claim at least some consistent evidence of a positive relationship between educational spending and educational output. Krueger (1999) estimates the effect of class size on student achievement using the Tennessee Student/Teacher

\footnotetext{
${ }^{1}$ The school inputs are per pupil expenditure, teach/pupil ratio, teacher education, teacher experience, and teacher salary.

${ }^{2}$ For example, only 20 percent(13 of 65 studies) of the relation showed positive and statistically significant results in the case of pupil per expenditures and at most 8 percent ( 9 of 112 studies) were positive and significant in the case of teach/pupil ratio.

${ }^{3}$ It is worth mentioning that Hanushek does not argue that increasing school expenditures make no difference. He claims additional school spending does not make an apparent difference on average, and expenditure increases are likely to raise school/student performance only if they are related to performance incentives for schools and students (Hanushek (1989), Levin (1989)).
} 
Achievement Ratio experiment (Project STAR), which is the only large-scale randomized experiment on class size in the United States. He concludes that performance on standardized tests increases when students are in small classes. This finding implies that school resources are positively correlated with student achievement. Case \& Deaton (1999) utilize South African data to estimate the effect of educational inputs. They exploit large variations in school resources across districts induced by apartheid. They find strong and significant effects of school resources on enrollment, educational achievement and test scores. However, the debate over the role of school resources in education still continues. ${ }^{4}$ This debate has important implications for education and economic policy. If increasing the quantity of school resources does not increase student achievement, education policy makers need to look at other policies to increase student performance instead of increasing school funding. ${ }^{5}$

One of the main reasons for an ambiguity in the relationship between expenditures and performance is a potential endogeneity problem. School expenditures might be positively correlated with the wealth of parents, thereby raising student performance both through intergenerational human capital transfers as well as higher school quality. Researchers might likely find ambiguous relationships between school inputs and student achievement because it is difficult to discern the effects of school budgets from parental wealth. In short, well financed schools are in areas where families are richer, rather than being randomly assigned. Therefore, the endogeneity problem is an underlying factor in the empirical findings.

One way of overcoming the endogeneity problem is to find instruments for the potentially endogenous school resource variables. In this regard, a number of influential studies used an instrumental variable (IV) approach. For example, Angrist \& Lavy (1999) use Maimonides’ rule governing maximum class size in Israel to estimate a positive relationship between class size and test scores. They estimate the effect of class size on student achievement using instruments constructed from Maimonides' Rule of $40 .{ }^{6}$ They find that a reduction in predicted class size

\footnotetext{
${ }^{4}$ See Krueger (2003) and Hanushek (2003).

${ }^{5}$ For example, using a Herfindahl index to measure competition, Hoxby (2000a) finds that an increase in competition is related to a statistically significant increase in student achievement.

${ }^{6}$ Maimonides' Rule is named after a twelfth century Rabbinic scholar, who identified a correlation between class size and students' achievements. This rule states that a class size may rise to an upper limit of 40 students. Once the number is reached the limit, another teacher must be appointed. Therefore, the class size is cut in half when total number of student is 41, so there are now two classes: one with 20 students and one with 21 students. Based on this rule,
} 
increased students' test scores. However, not all studies which employ the IV approach find positive effects from school resources. Hoxby (2000b) uses natural changes in population and externally imposed class size limits to generate instrumental variables to exploit the discontinuous changes in class size. Her results show no effect of a reduction in class size on student achievement. One problem with the IV approach is to appropriately identify instruments which influence the endogenous variables, namely school expenditures and/or resources, but which are not correlated with school performance. Finding proper instruments is always a challenge. Thus, as will be explained, our study adopts a different approach, namely a regression discontinuity (RD) strategy .

Each state in the U.S. has its own mechanism for determining the level of school expenditures. New York sets the level of school funding by school district budget referenda. ${ }^{7}$ Each year, school boards propose a budget to be approved by voters in a school district referendum, usually in May. If a majority of the voters do not approve the proposed budget, the school boards have to decide whether to hold a second budget vote in June or adopt a contingency budget. The second budget proposal often adopts a revised budget which is usually a shrunken proposal. If the proposed budget is defeated twice, then the board must adopt a contingency budget. Under a contingency budget, the district may not increase spending by more than a specified percentage of current year spending.

Under the school budget referendum system, a vote defeating a budget usually causes a more austere school budget and hence diminished expenditures per student in comparison to the previous school year. This study exploits the discontinuity in the likelihood of school budget referenda around the 50 percent voting share. It compares expenditures per student for school districts which barely approve or barely fail budget referenda. Exploiting the discontinuity around the 50 percent voting share results in a regression discontinuity (RD) design that isolates the exogenous variation in school district expenditures. Since the defeat of a budget vote impacts the magnitude of school spending, school districts' budget referenda provide an unusually reliable source of exogenous variation for analyzing the effects of school budgets. As will be explained

researchers can predict the class size when they know the total number of students in school (Angrist \& Lavy (1999)).

${ }^{7}$ More detailed information for the New York State school budget process is available in 'New York State School Aid Budget Process' at The New York State School Finance Reform Archive (http://finance.tc-library.org/Content.asp?uid=8356), and the following explanation for the budget process is largely based on this web-based article. Also see Ehrenberg et al. (2004). 
later, we adopt a fuzzy regression discontinuity (FRD) design because there is some ambiguity: an initial loss can result in a second referendum, which could lead to higher school expenditures. Similarly, a win could result in greater expenditures, but with a lag.

Recently several studies used a regression discontinuity design to exploit the relationship between school resources and school achievement. For example, Ludwig \& Miller (2007) use a discontinuity in Head Start funding across counties. The Office of Economic Opportunity provided technical grant-writing assistance for Head Start funding to the poorest 300 counties. This subsidy resulted 50-100 percent increase in Head Start funding between the poorest 300 counties and those counties just above the threshold. They find the increase in school funding is associated with 15 percent increase in the likelihood of attending some college. Cellini et al. (2010) study the effects of bond referenda to fund school facilities on school achievement and housing prices in California. They identify the effects of capital investment in new or renovated buildings by comparing school districts in which bond referenda passed or failed by narrow margins. They find only limited effects on school achievement by using a "dynamic" regression discontinuity design. Dee (2012) exploits discontinuous eligibility rules to estimate the effect of School Improvement Grants (SIG) on test-based performance of schools by using fuzzy regression discontinuity designs based on "lowest-achieving" and "lack of progress" thresholds. The U.S. Department of Education encouraged the persistently lowest-achieving public schools to implement school-reform models with substantial SIG in 2009. He finds the discontinuous likelihood of receiving SIG funds to cause significant improvements in school performance.

There are several different indicators of school district performance. They include test scores, dropout rates, transfer rates, and attrition rates for teachers. Among these indicators, this study uses student test scores and dropout rates at the high school level. Recent federal legislation, namely the No Child Left Behind (NCLB) Act of 2001, requires all states to report annual test results for students in order to measure adequate yearly progress. The NCLB also requires states to incorporate dropout and graduation rates into annual report cards. Because of the NCLB, the data for dropout rates and testing results are systematically managed and easily available.

First, we provide evidence that school expenditures per student typically increase following the approval of a proposed budget. Second, we show that increases in school expenditures decrease high school dropout rates. Third, we show the effects on student achievement are imprecise. 
This paper is organized as follows. Section 2 introduces the empirical strategy used in this study. Section 3 describes the data. Section 4 presents estimates, and Section 5 provides a conclusion.

\section{Estimation Method}

In this section we describe how the regression discontinuity (RD) strategy can be used to understand the relationship between school expenditures and school performance. The regression discontinuity (RD) approach is an evaluation technique designed as an alternative to the randomized experiment for evaluating social programs (van der Klaauw (2002)). In the case of experimental data the randomized assignment makes it possible to compare observations in a treatment group to those in a control group. Unlike experimental data, assignment in the RD design is not always random, and observations in the treatment group are different from those in the control group. However, if there is specific knowledge about the assignment rule and how observations are selected into the treatment group, the data from the RD design can serve as an alternative to those of a randomized experiment.

One such situation occurs where assignment is based on a selection cutoff point. In this situation the probability of getting assigned to the treatment group is a function of just achieving the cutoff point. For example, Thistlethwaite \& Campbell (1960), who first introduced the RD design, analyze the impact of student scholarships on career aspirations. They exploit the fact that the awards are made only when the students test scores exceed a cutoff score. They assume that students who score just below the cutoff score represent a valid control comparison group for those who score just above the score. Assignment near the cutoff point can be considered to be random because cognitive ability is similar for both groups of students within a small range of scores.

The existing literature stresses a distinction between two types of regression discontinuity design: the sharp RD design and the fuzzy RD design. ${ }^{8}$ In the sharp RD design all subjects receive their assigned treatment or control condition on the basis of an observed continuous assignment

\footnotetext{
8 One should consider a dynamic regression discontinuity design (Cellini et al., 2010) for multiple treatments occurring with nontrivial and unknown lags.
} 
variable. On the other hand, in the fuzzy RD design only some subjects receive the treatment even though they pass the cutoff. As such, in sharp RD, treatment occurs through a known deterministic rule. In fuzzy RD, treatment depends on the selection variable in a stochastic framework (Lee \& Lemieux (2010)).

Consider an equation characterizing the causal relationship between receiving a treatment, $T_{i}$ and outcome $Y_{i}$ :

$$
Y_{i}=\beta_{0}+\beta_{1} T_{i}+u_{i}
$$

When assignment to treatment is nonrandom, the estimation of $\beta_{1}$ has a selection bias because $E\left[u_{i} \mid T_{i}\right] \neq 0$. This endogeneity of $T_{i}$ leads to an inconsistent OLS estimate of $\beta_{1}$. This case is very common in empirical studies.

In the case of the RD design, there is a known treatment assignment mechanism and this mechanism depends on the value of an observed continuous variable, $v_{i}$. In this case, the probability of receiving treatment is a discontinuous function of $v_{i}$ at the cutoff point, $v_{c}$ : $T_{i}=1\left[v_{i} \geq v_{c}\right]$. Because $v_{i}$ is the only systematic determinant of treatment $T_{i}, v_{i}$ can capture any correlation between $T_{i}$ and $u_{i}$. Therefore, a dependency problem between $T_{i}$ and $u_{i}$ can be solved by specifying and including the conditional mean function $E\left[u_{i} \mid T_{i}, v_{u}\right]$.

Here Eq (1) can be rewritten as

$$
Y_{i}=\beta_{0}+\beta_{1} T_{i}+f\left(v_{i}\right)+\varepsilon_{i},
$$

where $\varepsilon_{i}=Y_{i}-E\left[Y_{i} \mid T_{i}, v_{i}\right]$. If $f\left(v_{i}\right)$ is correctly specified, the regression will consistently estimate $\beta_{1}$, which implies that correct specification of $f\left(v_{i}\right)$ is crucial (van der Klaauw (2002)). When $f\left(v_{i}\right)$ is linear $\beta_{1}$ is estimated by the distance between two linear parallel regression lines at the cutoff point, $v_{c}$, and the interaction between $f\left(v_{i}\right)$ and $T_{i}$ measures the distance between two linear regression lines which have different slopes at the cutoff point.

In the fuzzy RD design, assignment depends on $v_{i}$ in a stochastic manner, but the propensity score function $P\left(T_{i} \mid v_{i}\right)$ is known and the function jumps at the cutoff point, $v_{c}$. Therefore, the treatment effect, $\beta_{1}$ is identified by 


$$
\tau_{F R D}=\frac{\lim _{v \downarrow v_{c}} E\left[Y \mid v=v_{c}\right]-\lim _{v \uparrow v_{c}} E\left[Y \mid v=v_{c}\right]}{\lim _{v \downarrow_{c}} E\left[T \mid v=v_{c}\right]-\lim _{v \uparrow_{c}} E\left[T \mid v=v_{c}\right]},
$$

where the denominator $\lim _{v \downarrow_{c}} E\left[T \mid v=v_{c}\right]-\lim _{v \uparrow_{v_{c}}} E\left[T \mid v=v_{c}\right] \neq 0$ because of the known discontinuity of $v_{i}$ at $v_{c}$. In the sharp $\mathrm{RD}$ design this denominator, $\lim _{v \downarrow_{c}} E\left[T \mid v=v_{c}\right]-\lim _{v \uparrow_{v_{c}}} E\left[T \mid v=v_{c}\right]$, becomes one because all individuals get treatment when passing the threshold (Imbens \& Lemieux (2008)).

As long as the order of polynomials in the running variable and the data window, which is the size of the data, are identical for the first stage and the second stage, estimation of $\tau_{F R D}$ in Eq (3) is equivalent to a traditional instrumental variable approach. The first and second stage equations are:

$$
E\left[T_{i} \mid v_{i}\right]=f\left(v_{i}\right)+\gamma_{0} 1\left[v_{i} \geq v_{c}\right]
$$

and

$$
Y_{i}=\beta_{0}+\beta_{1} E\left[T_{i} \mid v_{i}\right]+g\left(v_{i}\right)+u_{i},
$$

where $u_{i}=Y_{i}-E\left[Y_{i} \mid v_{i}\right]$ and $\tau_{F R D}$ is known as a local Wald estimate (Hahn et al. (2001)).

In Section 4, we employ Eq (4) and Eq (5) to estimate the effect of expenditures on dropout rates and test scores for high school exit exams. As already mentioned, this is because school budget referenda do not always lead to a definitive result regarding the treatment. A loss can result in a new vote which could lead to an increase in school expenditures. Therefore, the results of budget referenda are able to explain some part of the variation in the change of school expenditures so that this property can be used to estimate the relationship between school districts expenditures and its performance.

Consider the model below to estimate the effects of school budget referenda on such school district performance as dropout rates and test scores:

$$
Y_{i}=\beta_{0}+\beta_{1} \% \Delta \text { Expenditure }_{i}+f\left(v_{i}\right)+\beta_{2} X_{i}+\varepsilon_{i}
$$

and

$$
\% \Delta \text { Expenditure }_{i}=\alpha_{0}+\alpha_{1} W_{I} N_{i}+f\left(v_{i}\right)+\alpha_{2} X_{i}+\eta_{i} \text {, }
$$

where the $f\left(v_{i}\right)$ is an unknown smooth function of the voting results for school district $i, X_{i}$ stands for the school districts' characteristics, $v_{i}$ is voting share, and $W I N_{i}=I \cdot\left[v_{i}>50\right]$ is a 
dummy variable which is one if the school budget referendum is passed and otherwise zero. The dummy variable $W I N_{i}$ is used as an instrument for the endogenous variable Expenditure $_{i}$ because the $W I N_{i}$ is assumed to be fully randomly assigned around 50 percent voting share. The $\beta_{1}$ expenditure coefficient, which is an estimate of the discontinuity in $Y_{i}$ at the 50 percent threshold, measures the causal effects of a budget vote win/lose on performance of school districts. The expenditure coefficient $\beta_{1}$ is the parameter of primary interest.

Correct specification of function $f\left(v_{i}\right)$ is required to obtain consistent estimation of $\beta$ and $\alpha$. As long as $f\left(v_{i}\right)$ is continuous in a neighborhood of the cutoff, it is possible to estimate the above equation, even with a flexible functional form for $f\left(v_{i}\right)$ such as a $p^{\text {th }}$-order polynomial. Interaction terms between the change of school expenditures (treatment assignment) and the voting share (assignment variable) can be included to allow for different trend functions or shapes on each side of the cutoff. As such, Eq (6) can be written as

$$
\begin{aligned}
Y_{i}= & \beta_{0}+\tau \Delta \operatorname{Exp}+\beta_{01}\left(v_{i}-v_{c}\right)+\beta_{02}\left(v_{i}-v_{c}\right)^{2}+\ldots+\beta_{0 p}\left(v_{i}-v_{c}\right)^{p} \\
& +\beta_{1} \Delta \operatorname{Exp}\left(v_{i}-v_{c}\right)+\beta_{2} \Delta \operatorname{Exp}\left(v_{i}-v_{c}\right)^{2}+\ldots+\beta_{p} \Delta \operatorname{Exp}\left(v_{i}-v_{c}\right)^{p}+\eta_{i}
\end{aligned}
$$

where centering $v_{i}$ at the $50 \%$ voting share $v_{c}$ is a normalization which ensures that the treatment effect at $v_{i}=v_{c}$ is the coefficient on $\Delta E x p$ in a regression model with interaction terms. Common practice employs up to 4th order polynomial terms, but sometimes the Akaike information criterion (AIC) is used for model selection. Similarly, these polynomials are interacted with the WIN ${ }_{i}$ dummy variable in Eq (7) which allows for different slopes and shapes on either side of the cutoff point.

This OLS approach with polynomials is a particularly simple way of allowing a flexible functional form in the $X \mathrm{~s}$. However, a drawback to this approach is that the global estimates of the regression function use data far from the cutoff. Recent studies introduce local linear regression as an alternative approach. But having chosen to use a local linear regression, the correct bandwidth and kernel function is key to identifying the treatment effect. 


\section{The Data Set}

\subsection{New York State School Budget Referenda}

Each spring, voters in the local school districts within the state vote on a budget that has been proposed by the local school district's board of education. If a budget is voted down, a school board of education has two choices: put a reduced spending budget proposal up for a second vote which is held in June; or go directly to a contingency budget. If the budget proposal fails on the second vote, the school district has to adopt a contingency budget. The contingency budget restricts the school district's spending in the next year to exceed no more than 120 percent of the Consumer Price Index or 4 percent, whichever is lower. ${ }^{9}$ Under this contingency budget, district officials usually cut some spending on administrative costs, on student supplies, on non-emergency building renovations and/or repairs, and on free community use of school facilities. Even though failing a budget referendum does not cause a significant reduction in spending because of other funding sources and reserved money left over from last year, the limited spending which is restricted in one year makes it difficult to increase the budget in the following year. The top panel in Table 1 presents the average vote share and the number of school districts for the 2003 to 2008 period in New York State that held budget votes. On average, 62 percent of voters adopt their school district budgets proposal. The percentage of school districts in which voters adopted proposed budgets fluctuated over time ranging from lows of 59.7 percent in 2004 to highs of 65.0 percent in 2007.

\subsection{Dropout Rates}

Dropout rates indicate the percentage of students who quit school before completing high school in a given year. Contrary to public belief, high school dropout rates in the United States have increased in recent years. For example, Swanson (2004) reports that average public high school graduation rates are between 68 and 71 percent, but that this figure is only about 50 percent

\footnotetext{
${ }^{9}$ The New York State School Finance Reform Archive provides a comprehensive description which is available at http://finance.tc-library.org/.
} 
in 2001 for black and Hispanic groups. This trend seems to be surprising and disturbing because the real wages of high school dropouts have declined since the early 1970s, in contrast to the wages of skilled workers, which have risen sharply (Heckman \& LaFontaine (2010)). We measure these dropout rates at the school district level from the New York State Education Department and the National Center for Educational Statistics (NCES) using 2003/2004 to 2008/2009 school year data. Table 1 reports the descriptive statistics for the sample. NCES provides dropout rates only for high school students.

The NCES data on which this study is based is conducted by the U.S. Department of Education. Because the NCES only includes information about public schools and school districts, it cannot be used for the graduation or dropout rates in the private schools. In addition, some states and school districts under report because the state accountability system contains significant incentives for school officers to report as transfers students whose status is unclear, rather than to report them as dropouts. ${ }^{10}$ Despite these drawbacks, the dropout rates from the NCES are most widely used measure of high school dropout rates (Heckman \& LaFontaine (2010)). ${ }^{11}$

\subsection{Test Exams}

Test scores provide a direct measure of student learning, which is one of the most important school outputs. This study uses two standardized exams: Regents Examinations (or high school exit exams) and proficiency tests administered at the elementary/middle school level. One advantage of using these test scores is that there is no issue of sample selection bias because all students must take these tests.

From the late 1990s, the public high-school students in New York have to pass the five Regents Examinations to receive a high-school Regent Diploma. When students do not pass all these exams by the end of twelfth grade, but finish their coursework, they receive a local diploma

\footnotetext{
10 According to the No Child Left Behind Act (NCLB), states, school districts and schools are required to report performance measures for their overall student population. The reported performance measures include standardized test scores, dropout rates and graduation rates.

11 Another alternative method for calculating dropout rates is using enrollment counts. But in this case there are numerous inconsistencies because student mobility cannot be fully controlled.
} 
or a certificate of attendance instead. For example, the cohort entered $9^{\text {th }}$ grade in the fall of 2002-2004 school year needs scale scores of at least 65 on five Regents Examinations to earn Regent Diploma. If they had scores of at least 55 in five subjects, they received a local diploma (NYSED 2010). Since the early 2000s, the requirement for the high-school diploma has been so more rigorous that the option of receiving a local diploma has been eliminated for the students who enter the $9^{\text {th }}$ grade in the fall of 2008. The five Regent Examination subjects are English, Mathematics, Science, U.S. History and Government, Global History and Geography.

The data from the New York State Education Department include recodes of proficiency test scores on English Language Arts (ELA) and Mathematics Assessment in grades 3-8 from the 2005/06 school year. The Education Department provides the percentage of students for each proficiency level as well as the average scores.

Even though high school exit exams provide five subjects, we utilize test scores only for Mathematics and English from the New York Chapter 655 Report for comparability since these are the subjects of the Proficiency test for elementary and middle school students. This study also includes the female labor-force participation (FLP) rate, the poverty rate and the median family income in school districts from the 2000 Census. Real minimum wage rates and county level unemployment rates are also included as proxy variables for local labor market conditions.

\section{Estimation Results}

This section is organized as follows: the first subsection estimates the effect of budget referenda on the change of school expenditures per student. Based on this result, the next two subsections report the estimation results for the effect of school expenditures on dropout rates and exit exam scores. Finally, the third subsection analyzes the effect of budget referenda on test scores using local linear regression. 


\subsection{School Budget Referenda and School Expenditures}

The key identifying assumption underlying the discontinuity-based approach is that school districts cannot control voting results around the 50 percent voting share. Figure 1 shows a histogram of the vote shares for school budget and there is no evidence of discontinuity around 50 percent voting share. Discontinuous changes in density at the threshold would violate the RD assumption because a jump around this threshold implies possible voter control over the assignment variable, in which case observations on either side may not be comparable (Lee \& Lemieux (2010)).

McCrary (2008) proposed a formal test for checking the density of a certain assignment variable, $r$, around the discontinuity. If the density of $r$ for each individual is continuous, then the marginal density of $r$ around the cutoff point, $c$, should be continuous, as well. He suggested that the discontinuity at the threshold be estimated by the log difference in height at the intercept:

$$
\theta=\ln \lim _{r \downarrow c} f(r)-\ln \lim _{r \uparrow_{c}} f(r),
$$

where $\lim _{r \downarrow c} f(r)$ and $\lim _{r} \uparrow_{c} f(r)$ are estimated values for the density just above and just below

the cutoff $c$. Once the $\hat{\theta}$ and its standard error $\hat{\sigma}_{\theta}$ are estimated, a formal t-test can be used for the null hypothesis $H_{0}: \theta=0$, which implies no statistical discontinuity at the cutoff point. We follow McCrary’s (2008) procedure to estimate $\hat{\theta}=0.1204$ and $\hat{\sigma}_{\theta}=0.1324$, yielding a t-value of 0.9094. Thus, we do not reject McCrary’s t-test of the null hypothesis of continuity

Table 2 presents the estimated results of Eq (7) and reports estimates of the change in expenditure per student when winning the budget referendum. Column (1)'s estimates are based on models that specify $f\left(v_{i}\right)$ as linear. Column (2)'s estimates maintain linearity, but include interaction terms, which allows for different slopes on either side of the 50 percent voting share. Columns (4) and (5) are based on more flexible specifications of the vote share with interaction terms. The dataset contains data on 465 school districts that come from 57 counties. It is possible that the educational outcomes within each county may not be independent, but would be independent between counties. In this case, this could lead to residuals that are not independent within counties. To account for the correlation in the residuals, the clustered standard errors are estimated based on the counties. The number of the clusters is 57 , and this is large enough to use 
the clustered standard errors because it exceeds 40 (Angrist \& Pishke, 2009).

Figure 2 shows the nonparametric spline smoothed estimates together with estimates of Eq (7) in which $f\left(v_{i}\right)$ is specified to be a continuous piecewise cubic function. These corresponding parameter estimates are presented in Table 2. Each point in the panel depicts the average school expenditures per student in 0.5 percent bins defined by the vote share relative to the threshold.

Figure 2 as well as the estimated discontinuity represented by the $\alpha_{1}$ coefficients in Table 2 show the importance of budget vote results. The distance from the lower fitted point on the left side to the upper point on the right side around the threshold measures the $\alpha_{1}$ coefficient. Obviously there is a jump around threshold, which implies that barely winning school districts have higher increased rates by 2 or 3 percent than barely defeated school districts. It is worth mentioning that the $\alpha_{1}$ distance coefficient depends on the functional form of $f\left(v_{i}\right)$. A cubic functional form is used to draw the fitted line in Figure 2, and it is clear that the distance will change according to other functional forms. The alternative distances are reported in the other columns in Table 2.

A special econometric issue is raised when some F-statistics in Table 2 yield low values. The OLS estimator is not only consistent, but also unbiased. However, the 2SLS estimator is consistent, but biased. Therefore, with a small sample, 2SLS estimates can differ systematically from the causal effect of interest. The 2SLS estimator is biased toward the probability limit of the corresponding OLS estimate especially when the instruments are weakly correlated with endogenous regressors and when there are too many overindentifying restrictions (Bound et al. (1995)). The source of the bias in 2SLS estimates is the randomness in estimates of the first stage predicted values, and this randomness causes the correlation between the first stage predicted values and the second stage error term. When the instruments are weak, the F-statistic becomes smaller as the number of instruments increases. In practice, and as a rule of thumb, researchers should pay attention to the weak instrument problem when the F-statistic is below roughly 10 in the first stage. ${ }^{12}$

\footnotetext{
${ }^{12}$ Angrist \& Pischke (2009) suggest that the limited information maximum likelihood (LIML) estimator can be used as an alternative because LIML is approximately median-unbiased for overidentified models. If the estimated results are similar when comparing overidentified 2SLS estimates with LIML, the 2SLS estimates are reliable because LIML is less precise than 2SLS, but it is less biased than 2SLS.
} 
In order to provide convincing results, it is necessary to check that the evidence found for a discontinuity is not spurious. There are several methods to check the robustness of these results. We use two methods. The first method requires us to select small samples around the discontinuity point by a certain bandwidth such as \pm 5 percent or \pm 2 percent intervals. ${ }^{13}$ The second is to show that discontinuities do not exist at other locations by using hypothetical breakpoints. We estimate 90 hypothetical breakpoints associated with discontinuities starting at 35 percent and increasing to 80 percent by 0.5 percent intervals, and record the t-statistic for the coefficient of Win Vote $\left(\alpha_{1}\right)$ which is associated with the discontinuity. If the 50 percent vote share is a true breakpoint, the t-statistic should be higher there than at any other hypothetical cutoff point. The relationship between the hypothetical discontinuity points and the t-statistic is plotted in Figure 3. The t-statistic is maximized at around 50 percent and is roughly symmetric around the true discontinuity point except for 2003/04 and 2004/05 school years.

\subsection{The Effect of School Expenditures on High School Dropout Rates and Test Scores}

\subsubsection{High School Dropout Rates}

When applied to school performance, Eq (6) can be written as

$$
\text { Dropout }_{i}=\beta_{0}+\beta_{1} \% \Delta E\left[\text { Expenditure }_{i} \mid v_{i}\right]+f\left(v_{i}\right)+\beta_{2} X_{s}+\varepsilon_{i},
$$

using an estimate of E[ Expenditure $\left.e_{i} \mid v_{i}\right]$ from a first-stage regression and where $f\left(v_{i}\right)$ represents an approximation of $E\left[u_{i} \mid v_{i}\right]$. In the first stage, the expenditure equation is specified as a flexible piecewise polynomial function, the estimates of which are presented in Table 2. Two stage estimates of the dropout equation are presented in Table 3.

Data for school years 2003/04 through 2004/05 include dropout rates only for school districts enrolling 1,000 or more students and the dropout rates data is disaggregated by grade at the school district level. However, starting with the 2005/06 school year, the data for dropout rates are available for every school district, but dropout counts and associated rates are only provided in aggregate form for grade 9 through grade 12. Because of these limitations, we estimate the dropout

\footnotetext{
13 The results for these robustness checks are presented in Appendix A.
} 
equations separately for the two periods.

The regression results for the 2003/04- 2004/05 school year are reported in Table 3. The first four columns give estimated discontinuities for the first through fourth order polynomials, which are fitted separately on the two sides of the threshold. Each row presents the estimated results for each grade. All signs of coefficients and their magnitudes are robust and significant except for the 11th grade, which implies that the discontinuities are not spurious because weak discontinuities are sensitive to the specification of the functional form. The results show that an increase in the percentage of school expenditures per student will result in a decrease of around 0.23 percent in the 12th grade dropout rate. According to Table 2, there are 2 or 3 percent gaps for the change in school expenditure around the 50 percent voting share. Therefore, the estimated results imply that the dropout rates for school districts which barely failed the budget vote are higher by 0.5 or 0.8 percent. Because the average dropout rate for the 12 th grade is 4.0 percent, an additional 8 percent increase in school expenditure could theoretically reduce the dropout rate by half.

Children in New York State are required to attend school from age 6 until age $16 .{ }^{14}$ In general, students who are under the compulsory age, need their parents' permission to drop out. Once students reach the upper age limit, they are no longer required to attend school and can drop out. Mostly these are students in the 10th grade who reach their sixteenth birthday. Therefore, there is a higher probability for 10th grade students to drop out, and for this reason school expenditures may have substantial effect on their enrollment decision.

As mentioned in the previous section, students in New York State must pass the five Regents Examination subjects. Students begin taking these exams in grade 10. If they fail the first exams, they have other opportunities to pass before completing 12th grade. Ou (2010) utilizes the high school exit exam in New Jersey and shows that students who barely failed the exam were more likely to drop out than those who barely passed. The dropout rates for the barely failed are much higher especially after taking the second test. Similarly, students who have weaker academic records and receive low test scores in New York State are more willing to drop out, even though there is another chance to retake the exams. The high probability for 12th grade students dropping

\footnotetext{
14 State law allows school districts to raise the upper age limit from 16 to 17 for the students in their district. The New York City, Buffalo, and Brockport school districts raised their compulsory age to 17.
} 
out could be explained by this high school exit exam.

Table 4 presents results for Eq (6). As mentioned in the previous section, since 2005/6, school-reported dropout rates collected by the National Center for Educational Statistics (NCES) are available only in aggregate form for grades 9 through 12. Table 4 is same as Table 3, except that the estimates are presented for all grades combined. Results in the first row are similar to those in Table 3. In the second row, we present results using limited information maximum likelihood (LIML). In Columns 3 and 4, the first stage F-statistics are 3.05 and 3.06, but the LIML estimates differ little from 2SLS in the first row, and the LIML standard errors are bigger. Thus, on balance, there seems to be little evidence of a weak instrumental variables problem.

To check the robustness of these results, we present estimates and confidence intervals using different windows around the 50 percent threshold beginning from \pm 2 percent and increasing to \pm 50 percent (i.e. using all observations) at \pm 0.5 percent intervals. The relationship between the width of the windows and the estimates and its 95 percent confidence intervals are plotted in Figure 4. The estimates converge to the estimates reported in Column 3 of Tables 3 and 4 for windows as small as 15 percent in the 2003/04-2008/9 school year and 5 percent in the 2003/04-2004/05 school years.

\subsubsection{High School Test Scores}

The above results show that increases in school expenditures per student have negative impacts on high school students' dropout rates. With this in mind, this subsection investigates whether increases in school expenditures have positive impacts on high school exit exam scores. This section begins the analysis by estimating models which are similar to those estimated above, but instead with exam performance as the outcome. Because the Chapter 655 Report neither provides average scores for each subject nor the percentages of the number of students in the four scoring levels, we use three outcome variables: (1) the percentage of the number of students in each scoring range, (2) the total exam points which are obtained by assigning points to scoring level and summing over all exams taken, and (3) the passing rates for high school exit exams.

Among the five exit exams, this study uses the exam scores of Mathematics and English which are first taken in 10th and 11th grade. The students take the exams usually in August, 
January and June, and the proportions of tested students scoring with under 54, $55 \sim 64$, $65 \sim 84$, and $85 \sim 100$ are reported for each subject of the Regents Examinations. ${ }^{15}$ The passing rates for Regent Diploma are the proportion of students whose score is higher than 65 points.

Table 5 and 6 report regression estimates of performance for exit exams. Positive effects of school expenditure increases should imply a negative sign for under 54 and a positive sign for those scoring $85 \sim 100$. The effects for those in the middle scoring ranges are ambiguous. The effects on Exam Points and Pass Rates should be positive. However, we find, regardless of functional form, the estimated coefficients are not significant and the signs are not consistent with theoretical predictions. Except for "Score Under 54”, the coefficients are not robust and depend on the model specification. For example, the coefficients of "Score 84 100" in Table 6 varies from 0.04 to 0.99 , based on functional forms. This evidence implies that the changes of school expenditures around 50 percent voting share do not have a significant impact on high school students' academic achievement.

Of course, one reason can be selectivity. If higher school expenditures decrease dropout rates, particularly of the less motivated, mean observed scores for all test-takers can fall, because now less motivated students comprise the overall pool of students. To get around this, we examine test scores of elementary and middle school students, since these students are less likely to drop out.

\subsubsection{Mathematics and English Language Test Scores for Elementary and Middle School}

The goal of the No Child Left Behind (NCLB) Act is to improve the quality of education nationally by increasing accountability. NCLB stipulates that states receiving federal funds are required to test students from Grades 3 through 8 in English Language Arts (ELA) in January and Mathematics in March to measure yearly progress. Under this legislation, school districts in New York State provide information on average scores as well as the percentage of students who scored at the four proficiency levels ${ }^{16}$ each school year since 2005/06. A summary of these is given Table

\footnotetext{
${ }^{15}$ We assign scores at the median of each range. For example, 27 points are assigned for the "under 54 ” range and 92.5 points assigned for "85-100" range.

16 The New York Education Department (www.nysed.gov) classifies the proficiency levels as follows: Level 1-Test scores indicate that these students have serious academic deficiencies and these students demonstrate no evidence of proficiency, Level 2-Test scores indicate that these students will need extra help to meet the standards and pass the Regents examinations and these students demonstrate some knowledge and skills, Level 3-Test scores indicate that
} 
1.

Tables 7 and 8 show the estimated results for average mathematics and ELA scores for elementary and middle school students based on Eq (4) and Eq (5). Estimated coefficients are not significant, and the size of the coefficients are quite small when considering that the average scores range from 663 to 689 point. More importantly, the coefficient values are sensitive to functional form. The coefficient values in the second column, Linear $\mathrm{x}$ Win, are larger than any of the other columns. For example, the estimated coefficient value for Grade 8 in the second column is 4.34, but it decreases to -1.33 when another polynomial term is added. Similar to the case of high school exit exams, there is no evidence that changes in school expenditures affect test scores for elementary and middle school students.

\subsection{Discussion}

The above analysis shows that changes in school expenditures per student reduce high school dropout rates, but they do not appear to increase the standardized test scores for high school students. The evidence that school expenditures can reduce the number of dropouts is important from a policy perspective. By dropping out, students significantly diminish their chance of finding a decent job, and thus suffer from reduced earnings. Moreover, there are significant social and economic costs to the rest of the community in which they live. Over the lifetime, a new graduate confers a net benefit to taxpayers of about $\$ 127,000$ so that reducing the current number of dropouts by half could yield $\$ 90$ billion public gain. ${ }^{17}$

Even though this study shows some positive evidence for the effect of school spending on educational outcomes, it does not pinpoint the specific expenditures that matter. Budget lines vary by school district. In New York State, the major categories include Instructional Salaries \& Fringe Benefits, Other Instruction, Operation \& Maintenance, Transportation, Debt Service, Board of Education \& Central Administration, and Other. Also, there are subcategories such as Energy,

student performance meets standards and, with continued steady growth, these students should pass the Regents examinations, and Level 4-Test scores indicate that student performance exceeds the standards and students are moving toward high performance on the Regents examinations and these students demonstrate superior knowledge and skills.

${ }^{17}$ The True Cost of High School Dropouts by H. Levin and C. Rouse, The New York Times, Jan 25, 2012. 
Health and Safety, Curriculum and Staff Development, Library Services, Food Services, etc. Generally speaking, a school district spends around 70 percent of its entire budget on salaries and employee benefits, 9 percent on Other Instruction and 7 percent on Operation \& Maintenance. ${ }^{18} \mathrm{~A}$ budget reduction may force a cut in academic programs, an increase in class size, the closure of school buildings and facilities, or a reduction in electives and extra-curricular activities.

It is important to realize that the allocation of school resources or school budgets to these categories varies by school district, and the school budget allocation is deliberately determined by superintendent or school board. When some school districts' budget referenda fail and their budgets are reduced, the budget allocation will differ from those of other school districts. The key issue here is varying resource allocations can lead to different educational outcomes, and detailed information of the budget allocation is required to estimate how the components of school expenditures affect performance. However, until now there are few, if any, studies on the effect of referenda on budget allocation. In a recent study, Nguyen-Hoang (2012) provides evidence that small city school districts (SCSD) in New York State reduce their instructional spending and increase class size, but preserve administrative spending in response to school districts budget referenda. Also Cellini et al. (2010) using school bond referenda for building school facilities in California suggest that well-targeted funds for school construction may raise social welfare, but they find weak impact on students test scores. Implicit in our study is that additional school resources lead to better student outcomes with respect to dropout rates. However, we do not examine the specific expenditures that lead to this outcome.

\section{Summary}

This paper considers the effect of school district budgets on student outcomes. Because various school district characteristics influence both school budgets as well as student performance, budget expenditures cannot be treated as an exogenous variable in an educational production function. We utilize a regression discontinuity (RD) quasi-experimental design to solve the endogeneity problem. This enables us to obtain reliable estimates of the effect of school

${ }^{18}$ State Education Department, Fiscal Analysis and Research Unit. Available at www.oms.nysed.gov. 
expenditures per student on test scores and dropout rates by comparing school districts in which school budget referenda passed or failed by narrow margins. School districts with close voting shares likely have different school budget growth. Therefore, the school districts around the threshold are different only in voting share and the amount of school budget which is caused by budget referenda.

Using school districts in New York State from the 2003/04 to 2008/09 school years, we provide clear evidence that the school districts at the margin of passing a budget vote are spending more than those failing at the margin. We find resulting increases in school expenditures cause the number of dropouts especially in 12th grades to decline. However, we are not able to find a systematic change in high school students' test scores. 


\section{Figures}

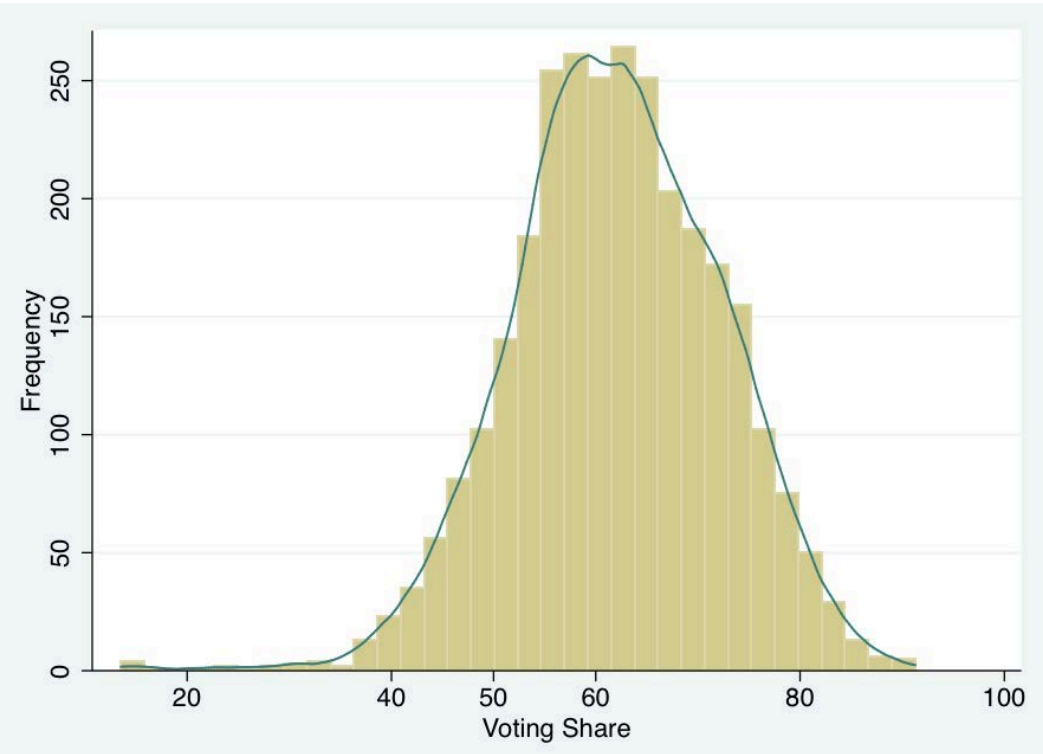

Figure 1. Vote Count by Vote Share. Samples include all school districts used in this paper from the 2003/04 to 2008/09 school years.

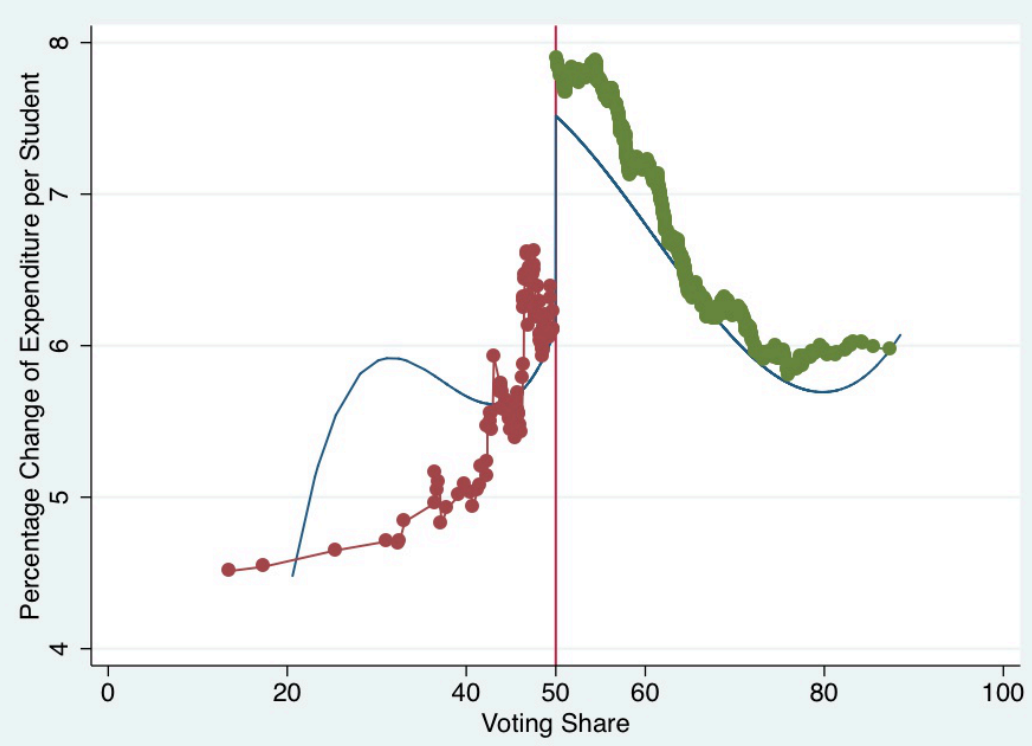

Figure 2. Estimated \% Change of Expenditure per Student and Voting Share. Points depict mean values which are calculated separately above and below the 50 percent voting share using a 0.5 bandwidth. 


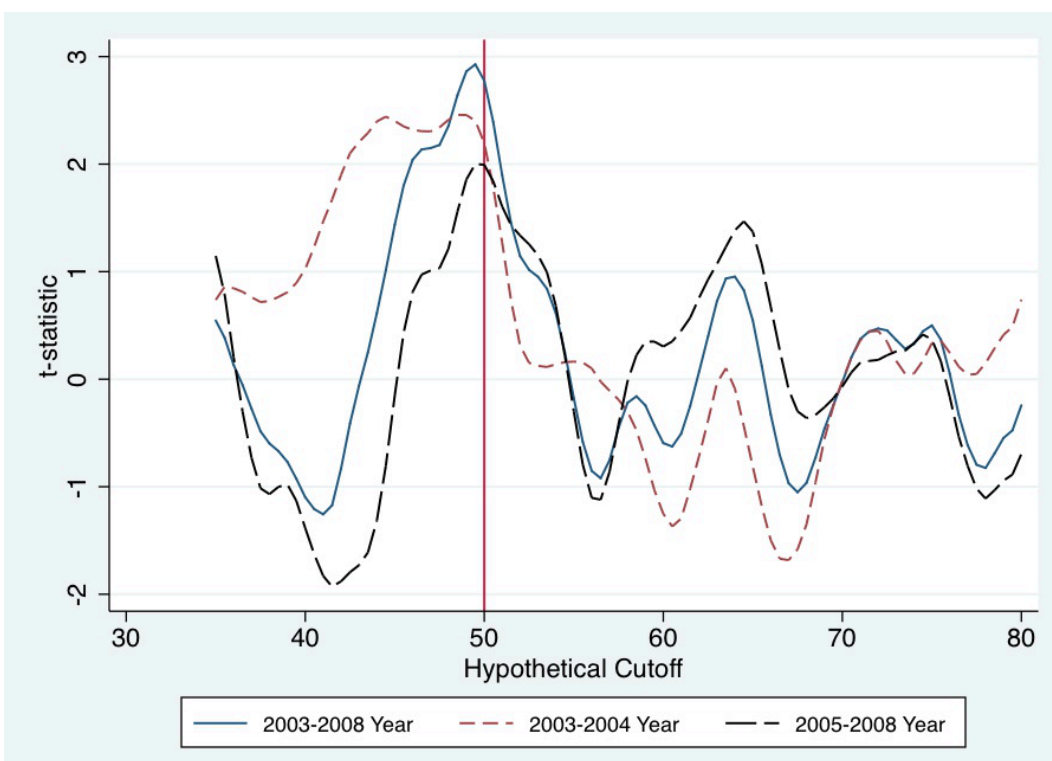

Figure 3. The lines represent smoothed t-statistics associated with hypothetical discontinuities from 35 to 80 percent with 0.5 bandwidth. The specification of the estimated models is a continuous piecewise cubic function.The corresponding parameter estimates are presented in Column 3 in Table 2.
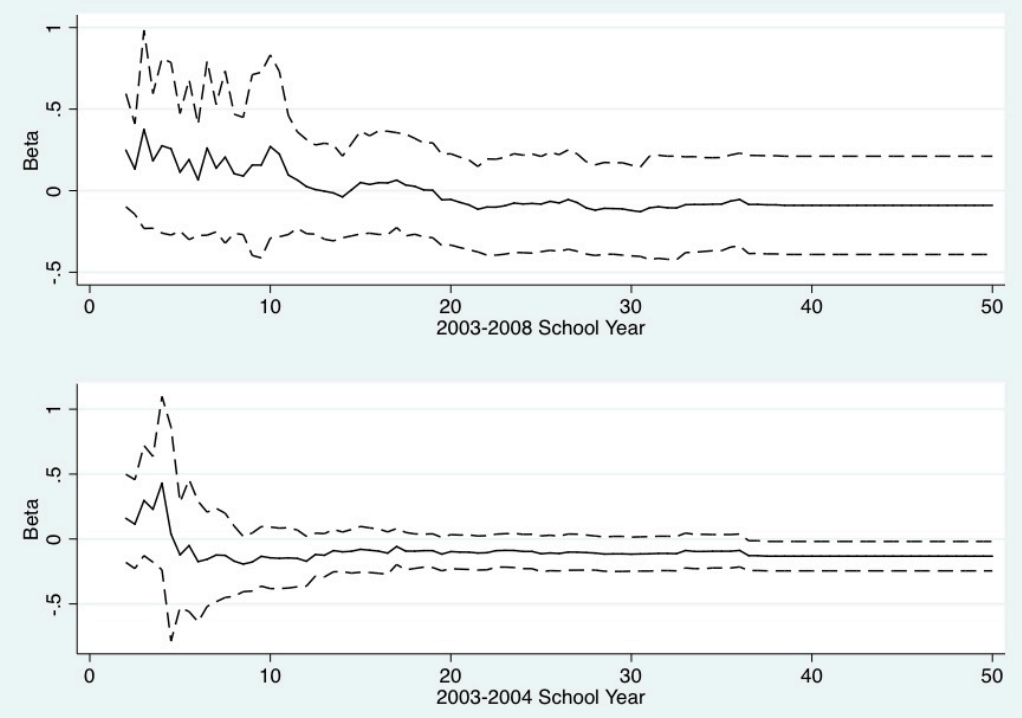

Figure 4. Estimates of $\beta_{1}$ and its 95 percent confidence intervals and the estimates obtained using different window widths around the 50 percent threshold. The specification of the estimated models is the continuous piecewise cubic function. Corresponding parameter estimates are presented in Column 3 of Tables 3 and 4. 


\section{Tables}

Table 1. Summary Statistics : NY 2003/04-2008/09 School Year

\begin{tabular}{|c|c|c|c|c|c|}
\hline Variable & Mean & Std.Dev. & Min. & Max. & $\mathrm{N}$ \\
\hline \multicolumn{6}{|l|}{ Voting Results and Expenditures } \\
\hline Vote Share(\%) ${ }^{a}$ & 62.010 & 10.16 & 13.518 & 91.304 & 2932 \\
\hline$\% \Delta$ of Expenditure per Student ${ }^{b}$ & 6.364 & 5.292 & -18.359 & 33.890 & 2930 \\
\hline \multicolumn{6}{|l|}{ High School Exit Exams $^{c}$} \\
\hline Math Proficiency Level 1(\%) & 3.72 & 4.86 & 0 & 100 & 920 \\
\hline Math Proficiency Level 2(\%) & 6.65 & 5.00 & 0 & 34 & 920 \\
\hline Math Proficiency Level 3(\%) & 55.50 & 13.22 & 0 & 86 & 920 \\
\hline Math Proficiency Level 4(\%) & 34.12 & 17.08 & 0 & 100 & 920 \\
\hline English Proficiency Level 1(\%) & 5.45 & 6.28 & 0 & 100 & 920 \\
\hline English Proficiency Level 2(\%) & 7.24 & 4.83 & 0 & 34 & 920 \\
\hline English Proficiency Level 3(\%) & 44.06 & 10.66 & 0 & 73 & 920 \\
\hline English Proficiency Level 4(\%) & 43.25 & 15.66 & 0 & 92 & 920 \\
\hline \multicolumn{6}{|l|}{ High School Dropout Rates $^{d}$} \\
\hline Dropout Rate, 9-12th Grade(\%) & 2.924 & 2.230 & 0 & 24.965 & 2932 \\
\hline Dropout Rate, 9th Grade(\%) & 1.571 & 2.51 & 0 & 27.965 & 930 \\
\hline Dropout Rate, 10th Grade(\%) & 2.639 & 2.945 & 0 & 25.926 & 930 \\
\hline Dropout Rate, 11th Grade(\%) & 3.767 & 3.263 & 0 & 26.531 & 930 \\
\hline Dropout Rate, 12th Grade(\%) & 4.002 & 3.161 & 0 & 21.277 & 930 \\
\hline \multicolumn{6}{|l|}{ Ele./Middle School Test Scores ${ }^{e}$} \\
\hline Math Mean Score for Grade 3 & 689.1 & 10.8 & 656.0 & 725 & 1228 \\
\hline Math Mean Score for Grade 4 & 685.1 & 11.9 & 652.8 & 724 & 1228 \\
\hline Math Mean Score for Grade 5 & 680.6 & 12.2 & 637.7 & 715 & 1228 \\
\hline Math Mean Score for Grade 6 & 677.0 & 12.4 & 630.9 & 715 & 1227 \\
\hline Math Mean Score for Grade 7 & 677.4 & 13.6 & 630.0 & 715 & 1236 \\
\hline Math Mean Score for Grade 8 & 670.8 & 14.1 & 625.7 & 705 & 1235 \\
\hline ELA Mean Score for Grade 3 & 673.4 & 10.2 & 640.6 & 702.3 & 1228 \\
\hline ELA Mean Score for Grade 4 & 671.3 & 10.4 & 637.4 & 706.6 & 1228 \\
\hline ELA Mean Score for Grade 5 & 673.5 & 9.2 & 638.5 & 706 & 1228 \\
\hline ELA Mean Score for Grade 6 & 667.2 & 8.3 & 639.3 & 694 & 1228 \\
\hline ELA Mean Score for Grade 7 & 665.9 & 9.3 & 625.3 & 692 & 1237 \\
\hline ELA Mean Score for Grade 8 & 663.3 & 10.6 & 625.9 & 695.8 & 1237 \\
\hline \multicolumn{6}{|l|}{ Covariates } \\
\hline FLP Rate in 2000 (\%) & 58.194 & 4.4 & 42.8 & 73.8 & 2930 \\
\hline Poverty Rate in 2000 (\%) & 8.673 & 4.9 & 1.2 & 24.5 & 2930 \\
\hline Median Family Income in 2000 & 58.3 & 19.8 & 33.8 & 200.0 & 2930 \\
\hline Unemployment Rates & 4.962 & 0.8 & 3.4 & 7.4 & 2926 \\
\hline
\end{tabular}

Sources: a. New York State Department of Education Office of Educational Management Services (www.emsc.nysed.gov/mgtserv/bvhist.htm). The Chapter 655 Reports each year (www.emsc.nysed.gov/irts/chapter655). 
Table 2. Impact of Winning a Budget Vote on the Percent Change of Expenditures per Student

\begin{tabular}{|c|c|c|c|c|}
\hline & $\begin{array}{l}\text { Linear } \\
\text { Coef./se }\end{array}$ & $\begin{array}{l}\text { Linear× Win } \\
\text { Coef./se }\end{array}$ & $\begin{array}{l}\text { Quad× Win } \\
\text { Coef./se }\end{array}$ & $\begin{array}{l}\text { Cubic } \times \text { Win } \\
\text { Coef./se }\end{array}$ \\
\hline \multicolumn{5}{|c|}{2003 - 2008 School Year, N=2,572 } \\
\hline $\operatorname{Win} \operatorname{Vote}\left(\alpha_{1}\right)$ & $1.7729 * * *$ & $1.3467 * * *$ & $2.0504 * * *$ & $1.9566 * * *$ \\
\hline & $(.3786)$ & $(.4856)$ & $(.6574)$ & $(.5734)$ \\
\hline R-squared & .040 & .042 & .043 & .043 \\
\hline F statistic & 9.497 & 8.982 & 7.854 & 7.843 \\
\hline \multicolumn{5}{|c|}{2003 - 2004 School Year, N=917 } \\
\hline $\operatorname{Win} \operatorname{Vote}\left(\alpha_{1}\right)$ & $2.9135 * * *$ & $2.2275^{* *}$ & $3.0852 * * *$ & $3.0815 * * *$ \\
\hline & (.6588) & $(1.0158)$ & $(1.1427)$ & $(.9559)$ \\
\hline R-squared & .086 & .091 & .092 & .094 \\
\hline F statistic & 11.004 & 10.024 & 8.071 & 8.090 \\
\hline \multicolumn{5}{|c|}{2006 - 2008 School Year, N=1,169 } \\
\hline Win $\operatorname{Vote}\left(\alpha_{1}\right)$ & .9842 & .8512 & $2.3892 * *$ & $2.0545^{* *}$ \\
\hline & $(.6747)$ & $(.7816)$ & $(1.0382)$ & $(.9436)$ \\
\hline R-squared & .015 & .015 & .021 & .020 \\
\hline F statistic & 1.612 & 1.452 & 3.053 & 3.064 \\
\hline \multicolumn{5}{|c|}{$\begin{array}{l}\text { Notes. Each cell represents a separate regression. The baseline specification is } \\
\% \Delta \text { Expenditure } e_{i}=\alpha_{0}+\alpha_{1} W I N_{i}+f\left(v_{i}\right)+\alpha_{2} X_{s}+\eta_{i} \text { and } f\left(v_{i}\right) \text { is the continuous piecewise } \\
\text { function i.e. } f\left(v_{i}\right)=\sum_{k=1}^{3} \beta_{0 k}\left(v_{i}-v_{c}\right)^{k}+\sum_{k=1}^{3} W I N_{i} \beta_{k}\left(v_{i}-v_{c}\right)^{k} \text {, where } v_{c} \text { is a } 50 \text { percent voting } \\
\text { share. Standard errors clustered by counties are in parentheses. }\end{array}$} \\
\hline \multicolumn{5}{|c|}{$\begin{array}{l}\text { Table 3. 2SLS Estimates for the Change in Dropout Rates by Grades (2003/04 - 2004/05 School } \\
\text { Year, N=863 ) }\end{array}$} \\
\hline$\% \Delta$ Expenditure $\left(\beta_{1}\right)$ & $\begin{array}{c}\text { Linear } \\
\text { Coef./se }\end{array}$ & $\begin{array}{l}\text { Linear } \times \text { Win } \\
\text { Coef./se }\end{array}$ & $\begin{array}{l}\text { Quad } \times \text { Win } \\
\text { Coef./se }\end{array}$ & $\begin{array}{l}\text { Cubic } \times \text { Win } \\
\text { Coef./se }\end{array}$ \\
\hline 9th Grade & $\begin{array}{l}-.1136^{* * *} \\
(.0401)\end{array}$ & $\begin{array}{l}-.1629^{* * *} \\
(.0461)\end{array}$ & $\begin{array}{l}-.1519^{* * *} \\
(.0432)\end{array}$ & $\begin{array}{l}-.1467^{* * *} \\
(.0423)\end{array}$ \\
\hline 10th Grade & $\begin{array}{l}-.2183^{* * *} \\
(.0561)\end{array}$ & $\begin{array}{l}-.2679 * * * \\
(.0627)\end{array}$ & $\begin{array}{l}-.2618^{* * *} \\
(.0602)\end{array}$ & $\begin{array}{l}-.2632 * * * \\
(.0591)\end{array}$ \\
\hline 11th Grade & $\begin{array}{l}-.0543 \\
(.0570)\end{array}$ & $\begin{array}{l}-.0960 \\
(.0612) \\
\end{array}$ & $\begin{array}{l}-.0919 \\
(.0607)\end{array}$ & $\begin{array}{l}-.0933 \\
(.0600)\end{array}$ \\
\hline 12th Grade & $\begin{array}{l}-.1774 * * * \\
(.0646)\end{array}$ & $\begin{array}{l}-.2358 * * * \\
(.0705)\end{array}$ & $\begin{array}{l}-.2313 * * * \\
(.0695)\end{array}$ & $\begin{array}{l}-.2314 * * * \\
(.0687)\end{array}$ \\
\hline 9th - 12th Grade & $\begin{array}{l}-.1392^{* * *} \\
(.0381)\end{array}$ & $\begin{array}{l}-.1915^{* * *} \\
(.0427)\end{array}$ & $\begin{array}{l}-.1843^{* * *} \\
(.0412)\end{array}$ & $\begin{array}{l}-.1837^{* * *} \\
(.0405)\end{array}$ \\
\hline
\end{tabular}

Notes. Specification: DropoutRate ${ }_{i}=\beta_{0}+\beta_{1}$ Expenditure $_{i}+f\left(v_{i}\right)+\beta_{2} X_{s}+\varepsilon_{i}$ and $f\left(v_{i}\right)=\sum_{k=1}^{3} \beta_{0 k}\left(v_{i}-v_{c}\right)^{k}+\sum_{k=1}^{3} W_{I N} \beta_{k}\left(v_{i}-v_{c}\right)^{k}$, where $v_{c}$ is a 50 percent voting share. All 2SLS results use $W_{I} N_{i}$ as an instrument for Change of Expenditure per student.

Data : Dropout rates are based on the survey of National Center for Education Statistics(NCES). NCES provides overall dropout rate(9th-12th) for school year 2003/04 through 2007/08. However, the dropout rates from each of grades 9th through 12th are only available for school year 2003/04 and 2004/05. 
Table 4. 2SLS Estimates for the Change of Dropout Rates (2003/04 - 2008/09 School Year, $N=$ 1,971)

\begin{tabular}{|c|c|c|c|}
\hline $\begin{array}{c}\text { Linear } \\
\text { Coef./se }\end{array}$ & $\begin{array}{c}\text { Linear× Win } \\
\text { Coef./se }\end{array}$ & $\begin{array}{c}\text { Quad } \times \text { Win } \\
\text { Coef./se }\end{array}$ & $\begin{array}{c}\text { Cubic } \times \text { Win } \\
\text { Coef./se }\end{array}$ \\
\hline \multicolumn{4}{|c|}{$\% \Delta$ Expenditure $\left(\beta_{1}\right):$ 2SLS } \\
\hline $\begin{array}{l}-.0687 \\
(.0721) \\
\end{array}$ & $\begin{array}{c}-.2105^{*} \\
(.1088) \\
\end{array}$ & $\begin{array}{c}-.2599 * * \\
(.1237) \\
\end{array}$ & $\begin{array}{c}-.1961 * \\
(.1015) \\
\end{array}$ \\
\hline \multicolumn{4}{|c|}{$\% \Delta$ Expenditure $\left(\beta_{1}\right)$ : LIML } \\
\hline $\begin{array}{c}.4816 \\
(.1441)\end{array}$ & $\begin{array}{c}-.1438 \\
(5.3927)\end{array}$ & $\begin{array}{l}-.1457 \\
(.1824)\end{array}$ & $\begin{array}{l}-.1349 \\
(.3560)\end{array}$ \\
\hline
\end{tabular}

Notes. See notes on Table 3

Table 5. Effect on High School Exit Exams: Mathematics (N=917, 2003/04 - 2004/05 School Year)

\begin{tabular}{lcccc}
\hline$\% \Delta$ Expenditure $\left(\beta_{1}\right)$ & $\begin{array}{c}\text { Linear } \\
\text { Coef./se }\end{array}$ & $\begin{array}{c}\text { Linear } \times \text { Win } \\
\text { Coef./se }\end{array}$ & $\begin{array}{c}\text { Quad } \times \text { Win } \\
\text { Coef./se }\end{array}$ & $\begin{array}{c}\text { Cubic } \times \text { Win } \\
\text { Coef./se }\end{array}$ \\
\hline Test Score & .4150 & .3505 & .5038 & .5451 \\
Under 54 & $(.2589)$ & $(.4147)$ & $(.3923)$ & $(.3439)$ \\
\hline Test Score & .2765 & .2000 & .5126 & .5947 \\
$55 \sim 64$ & $(.2717)$ & $(.4362)$ & $(.3912)$ & $(.3661)$ \\
\hline Test Score & .4249 & .0013 & .0732 & -.3549 \\
$65 \sim 84$ & $(.6463)$ & $(1.0715)$ & $(.8965)$ & $(.7922)$ \\
\hline Test Score & -1.1163 & -.5517 & -1.0896 & -.7849 \\
$85 \sim 100$ & $(.9449)$ & $(1.4768)$ & $(1.1908)$ & $(1.0122)$ \\
\hline Exam Points $^{a}$ & -2.2227 & -1.4526 & -2.6097 & -2.4698 \\
& $(1.5815)$ & $(2.4574)$ & $(2.0853)$ & $(1.8084)$ \\
\hline Passing Rates $^{b}$ & -.6914 & -.5504 & -1.0163 & $-1.1398 *$ \\
& $(.4972)$ & $(.7993)$ & $(.7346)$ & $(.6706)$ \\
\hline
\end{tabular}

Notes. See notes on Table 3. a. The exam points are obtained by assigning points to letter grades(Level1=1, ... , Level4=4). b. The percentage of student whose scores are higher than 65 point. 
Table 6. Effect on High School Exit Exams: English (N=917, 2003/04 - 2004/05 School Year)

\begin{tabular}{ccccc}
\hline$\% \Delta$ Expenditure $\left.\left(\beta_{1}\right)\right)$ & $\begin{array}{c}\text { Linear } \\
\text { Coef./se }\end{array}$ & $\begin{array}{c}\text { Linear× Win } \\
\text { Coef./se }\end{array}$ & $\begin{array}{c}\text { Quadx Win } \\
\text { Coef./se }\end{array}$ & $\begin{array}{c}\text { Cubic } \times \text { Win } \\
\text { Coef./se }\end{array}$ \\
\hline Test Score & .3739 & .4088 & .3632 & .3788 \\
Under 54 & $(.2681)$ & $(.4386)$ & $(.3025)$ & $(.2785)$ \\
\hline Test Score & .0874 & .0862 & .1211 & .1684 \\
$55 \sim 64$ & $(.2090)$ & $(.3498)$ & $(.2403)$ & $(.2195)$ \\
\hline Test Score & -.9055 & -1.4904 & -.5722 & -.5914 \\
$65 \sim ~ 84$ & $(.6286)$ & $(1.2277)$ & $(.6471)$ & $(.5649)$ \\
\hline Test Score & .4443 & .9954 & .0879 & .0442 \\
$85 \sim 100$ & $(.7769)$ & $(1.3586)$ & $(.8045)$ & $(.6793)$ \\
\hline Exam Points $^{a}$ & -.3908 & .0917 & -.7597 & -.8817 \\
& $(1.2865)$ & $(2.0607)$ & $(1.4060)$ & $(1.2260)$ \\
\hline Passing Rates & -.4949 & -.5848 & -.5606 & -.6328 \\
& $(.4251)$ & $(.7221)$ & $(.6004)$ & $(.5416)$ \\
\hline
\end{tabular}

Notes. See notes on Table 3. a. The exam points are obtained by assigning points to letter grades(Level1=1, ... , Level4=4).

Table 7. 2SLS Estimates for Elementary/Middle School Average Mathematics Scores by Grades 3 to 8 .

\begin{tabular}{ccccc}
\hline & $\begin{array}{c}\text { Linear } \\
\text { Coef./se }\end{array}$ & $\begin{array}{c}\text { Linear× Win } \\
\text { Coef./se }\end{array}$ & $\begin{array}{c}\text { Quad } \times \text { Win } \\
\text { Coef./se }\end{array}$ & $\begin{array}{c}\text { Cubic } \times \text { Win } \\
\text { Coef./se }\end{array}$ \\
\hline Grade 3 & 2.4041 & 3.5849 & -.9132 & .5176 \\
& $(2.0310)$ & $(3.1343)$ & $(1.4269)$ & $(1.1794)$ \\
\hline Grade 4 & 1.8454 & 2.7064 & -.0423 & .1840 \\
& $(1.8289)$ & $(2.6866)$ & $(1.5596)$ & $(1.3526)$ \\
\hline Grade 5 & .1548 & .3932 & -1.9993 & -.9089 \\
& $(2.0520)$ & $(2.3123)$ & $(2.1314)$ & $(1.5004)$ \\
\hline Grade 6 & 2.5239 & 3.8465 & .1017 & .4671 \\
& $(2.2793)$ & $(3.5123)$ & $(1.5750)$ & $(1.3178)$ \\
\hline Grade 7 & 2.7959 & 4.6495 & -.9316 & .3278 \\
& $(2.3190)$ & $(3.9535)$ & $(1.5505)$ & $(1.3518)$ \\
\hline Grade 8 & 2.8942 & 4.3388 & -1.3335 & .4238 \\
& $(2.3320)$ & $(3.7256)$ & $(1.5734)$ & $(1.2788)$ \\
\hline
\end{tabular}

Notes. Specification: AverageScore $_{i}=\beta_{0}+\beta_{1}$ Expenditure $_{i}+f\left(v_{i}\right)+\beta_{2} X_{s}+\varepsilon_{i} \quad$ and $f\left(v_{i}\right)=\sum_{k=1}^{3} \beta_{0 k}\left(v_{i}-v_{c}\right)^{k}+\sum_{k=1}^{3} W I N_{i} \beta_{k}\left(v_{i}-v_{c}\right)^{k}$, where $v_{c}$ is a 50 percent voting share. All 2SLS results use $W_{I N}$ as an instrument for Change of Expenditure per student. All numbers reported in table are $\beta_{1}$ s. 
Table 8. 2SLS Estimates for Elementary/Middle School Average English/Language Scores by Grades 3 to 8.

\begin{tabular}{ccccc}
\hline & $\begin{array}{c}\text { Linear } \\
\text { Coef./se }\end{array}$ & $\begin{array}{c}\text { Linear× Win } \\
\text { Coef./se }\end{array}$ & $\begin{array}{c}\text { Quad } \times \text { Win } \\
\text { Coef./se }\end{array}$ & $\begin{array}{c}\text { Cubic × Win } \\
\text { Coef./se }\end{array}$ \\
\hline Grade 3 & 1.2080 & 1.3946 & .3986 & .8578 \\
& $(1.4108)$ & $(1.9499)$ & $(1.2806)$ & $(1.4475)$ \\
\hline Grade 4 & .6608 & .8780 & .7129 & .4349 \\
& $(1.1885)$ & $(1.5910)$ & $(1.2950)$ & $(1.3184)$ \\
\hline Grade 5 & -1.4003 & -1.4666 & -1.7127 & -1.3991 \\
& $(1.8842)$ & $(2.1412)$ & $(1.7320)$ & $(1.5099)$ \\
\hline Grade 6 & -.5516 & .0100 & -.0051 & -.4181 \\
& $(1.6758)$ & $(1.8453)$ & $(1.4576)$ & $(1.2820)$ \\
\hline Grade 7 & .1653 & .1959 & .1410 & -.4196 \\
& $(1.0250)$ & $(1.3079)$ & $(.9610)$ & $(1.0154)$ \\
\hline Grade 8 & 1.0191 & 1.3987 & .7460 & .4500 \\
& $(1.4172)$ & $(1.9006)$ & $(1.2659)$ & $(1.3226)$ \\
\hline
\end{tabular}

See Table notes in Table 7. 


\section{References}

Angrist, Joshua D and Victor Lavy. 1999. “Using Maimonides’ Rule to Estimate the Effect of Class Size on Scholastic Achievement.” The Quarterly Journal of Economics, 114(2): 533575.

Angrist, Joshua David and Jörn-Steffen Pishke. 2009. Mostly Harmless Econometrics: An Empiricist's Companion. Princeton University Press, Princeton.

Bound, John, David Jaeger,and Regina Baker. 1995. "Problems with Instrumental Variables Estimation When the Correlation Between the Instruments and the Endogeneous Explanatory Variable is Weak.” Journal of the American Statistical Association, 90(430): 443-450.

Case, Anne and Angus Deaton. 1999. “School Inputs and Educational Outcomes in South Africa.” The Quarterly Journal of Economics, 114(3): 1047-1084.

Cellini, Stephanie, Riegg Fernando Ferreira, and Jesse Rothstein. 2010. “The Value of School Facility Investments: Evidence from a Dynamic Regression Discontinuity Design.” The Quarterly Journal of Economics, 125(1): 215-261.

Coleman, James Samuel. 1966. Equality of Educational Opportunity. U.S. Dept. of Health, Education, and Welfare, Office of Education, Washington.

Dee, Thomas. 2012. “School Turnarounds: Evidence from the 2009 Stimulus,” NBER Working Paper 17990.

Ehrenberg, Ronald, Randy Ehrenberg, Christopher Smith and Liang Zhang. 2004. "Why Do School District Budget Referenda Fail?” Educational Evaluation and Policy Analysis, 26(2): 111-125.

Guido W. Imbens and Thomas Lemieux. 2008. "Regression Discontinuity Designs: A Guide to Practice.” Journal of Econometrics, 142(2): 615 - 635.

Hahn, Jinyong, Petra Todd, and Wilbert Van der Klaauw. 2001. "Identification and Estimation of Treatment Effects with a Regression-Discontinuity Design.” Econometrica, 69(1): 201-209. Hanushek, Eric. 1997. “Assessing the Effects of School Resources on Student Performance: An Update.” Educational Evaluation and Policy Analysis, 19(2): 141-164.

Hanushek, Eric. 1986. "The Economics of Schooling: Production and Efficiency in Public Schools.” Journal of Economic Literature, 24(3): 1141-1177. 
Hanushek, Eric. 2003. “The Failure of Input-Based Schooling Policies.” The Economic Journal, 113(485): F64-F98.

Hanushek, Eric. 1989. “The Impact of Differential Expenditures on School Performance.” Educational Researcher, 18(4): 45-62.

Hedges, Larry, Richard Laine and Rob Greenwald. 1994. “An Exchange: Part I: Does Money Matter? A Meta-Analysis of Studies of the Effects of Differential School Inputs on Student Outcomes.” Educational Researcher, 23(3): 5-14.

Hedges, Larry, Richard Laine and Rob Greenwald. 1994. "Money Does Matter Somewhere: A Reply to Hanushek.” Educational Researcher, 23(4): 9-10.

Hoxby, Caroline. 2000. "Does Competition among Public Schools Benefit Students and Taxpayers?” The American Economic Review, 90(5): 1209-1238.

Hoxby, Caroline. 2000. "The Effects of Class Size on Student Achievement: New Evidence from Population Variation.” The Quarterly Journal of Economics, 115(4): 1239-1285.

James J Heckman and Paul LaFontaine. 2010. "The American High School Graduation Rate: Trends and Levels.” The Review of Economics and Statistics, 92(2): 244-262.

Krueger, Alan. 1999. "Experimental Estimates of Education Production Functions." The Quarterly Journal of Economics, 114(2): 497-532.

Krueger, Alan. 2003. "Economic Considerations and Class Size.” The Economic Journal, 113(485):F34-F63.

Lee, David S. and Thomas Lemieux. 2010. "Regression Discontinuity Designs in Economics.” Journal of Economic Literature, 48(2): 281-355.

Ludwig, Jens and Douglas L. Miller. 2007. “Does head start improve children’s life changes? Evidence from a regression discontinuity design,” The Quarterly Journal of Economics, 122(1) 159-208.

McCrary, Justin. 2008. "Manipulation of the running variable in the regression discontinuity design: A density test.” Journal of Econometrics, 142(2): 698 - 714.

New York Education Department. 2010. General Education \& Diploma Requirements, Commencement Level (Grades 9-12). Office of Elementary, Middle, Secondary, and Continuing Education, Albany, NY.

Nguyen-Hoang, Phuong. 2012. "Fiscal Effects of Budget Referendums: Evidence from New York School Districts.” Public Choice, 150: 77-95. 
Ou, Dongshu. 2012. “To leave or not to leave? A Regression Discontinuity Analysis of the Impact of Failing the High School Exit Exam.” Economics of Education Review, 29(2): 171 - 186.

Swanson, Christopher. 2004. “Who Graduates? Who Doesn’t? A Statistical Portrait of Public High School Graduation, Class of 2001.” The Urban Institute.

Thistlethwaite, Donald and Donald T. Campbell. 1960. "Regression-Discontinuity Analysis: An Alternative to the Ex Post Facto Experiment.” Journal of Educational Psychology, 51(6): 309-317.

van der Klaauw, Wilbert. 2002. "Estimating the Effect of Financial Aid Offers on College Enrollment: A Regression-Discontinuity Approach.” International Economic Review, 43(4): 1249-1287. 
Appendix A. Estimation Results of Dropout Rates Using Discontinuity Samples

In order to check the robustness of the results in Table 3 and Table 4, this appendix offers RD estimates with varying window widths of voting shares. Table A.1 and Table A.2 reproduce the results reported in Table 3 and Table 4 . The first three columns show the results for a \pm 5 voting shares and last three columns report for \pm 2 voting shares around 50 percent voting share. As expected, the results using smaller discontinuity samples show larger standard errors than the previous results. However, the dropout rates for 9-12th and 12th in the first three columns are very similar to those using whole samples. The results for 9-12th dropout rates are still significant and the coefficients are close to those in Table 3. Broadly speaking, the results are robust the voting share windows used in the estimation.

Table A.1. 2SLS Estimates for Dropout Rates (Discontinuity Sample: $\pm 5 \%$ and $\pm 2 \%, 2003 / 04$ and 2004/05 School Year)

\begin{tabular}{|c|c|c|c|c|c|c|}
\hline Grade & $\begin{array}{l}\text { IV(5\%) } \\
\text { Coef./se }\end{array}$ & $\begin{array}{c}\text { Linear(5\%) } \\
\text { Coef./se }\end{array}$ & $\begin{array}{c}\text { Linear } \times \\
\text { WIN(5\%) } \\
\text { Coef./se }\end{array}$ & $\begin{array}{l}\text { IV(2\%) } \\
\text { Coef./se }\end{array}$ & $\begin{array}{c}\text { Linear(2\%) } \\
\text { Coef./se }\end{array}$ & $\begin{array}{c}\text { Linear× } \\
\text { WIN(2\%) } \\
\text { Coef./se }\end{array}$ \\
\hline $\begin{array}{l}\text { 9-12th: } \beta_{1} \\
\text { No. of Obs. }\end{array}$ & $\begin{array}{c}-1268^{* *} \\
(.0544) \\
267 \\
\end{array}$ & $\begin{array}{c}-.0962^{*} \\
(.0499) \\
267\end{array}$ & $\begin{array}{c}-.0988^{* *} \\
(.0502) \\
267 \\
\end{array}$ & $\begin{array}{c}-.0740 \\
(.0572) \\
98 \\
\end{array}$ & $\begin{array}{c}-.1284^{*} \\
(.0680) \\
98 \\
\end{array}$ & $\begin{array}{c}-.0736 \\
(.0539) \\
98 \\
\end{array}$ \\
\hline $\begin{array}{c}\text { 9th: } \beta_{1} \\
\text { No. of Obs. }\end{array}$ & $\begin{array}{c}-.1226^{*} \\
(.0724) \\
289\end{array}$ & $\begin{array}{c}-.0885 \\
(.0666) \\
289\end{array}$ & $\begin{array}{c}-.0910 \\
(.0668) \\
289\end{array}$ & $\begin{array}{c}-.0900 \\
(.0814) \\
106\end{array}$ & $\begin{array}{c}-.1518 \\
(.1049) \\
106\end{array}$ & $\begin{array}{c}-.0951 \\
(.0763) \\
106\end{array}$ \\
\hline $\begin{array}{c}\text { 10th : } \beta_{1} \\
\text { No. of Obs. }\end{array}$ & $\begin{array}{c}-.1236^{*} \\
(.0644) \\
310 \\
\end{array}$ & $\begin{array}{c}-.0961 \\
(.0631) \\
310 \\
\end{array}$ & $\begin{array}{c}-.1000 \\
(.0633) \\
310 \\
\end{array}$ & $\begin{array}{c}-.0444 \\
(.0805) \\
122 \\
\end{array}$ & $\begin{array}{c}-.0985 \\
(.0895) \\
122 \\
\end{array}$ & $\begin{array}{c}-.0500 \\
(.0731) \\
122 \\
\end{array}$ \\
\hline $\begin{array}{l}\text { 11th : } \beta_{1} \\
\text { No. of Obs. }\end{array}$ & $\begin{array}{c}-.0922 \\
(.0629) \\
323\end{array}$ & $\begin{array}{c}-.0918 \\
(.0624) \\
323\end{array}$ & $\begin{array}{c}-.0940 \\
(.0625) \\
323\end{array}$ & $\begin{array}{c}-.0515 \\
(.0714) \\
117\end{array}$ & $\begin{array}{c}-.0798 \\
(.0776) \\
117\end{array}$ & $\begin{array}{c}-.0530 \\
(.0682) \\
117\end{array}$ \\
\hline $\begin{array}{c}\text { 12th : } \beta_{1} \\
\text { No. of Obs. }\end{array}$ & $\begin{array}{c}-.1462 * * \\
(.0720) \\
328\end{array}$ & $\begin{array}{c}-.1345^{* *} \\
(.0673) \\
328\end{array}$ & $\begin{array}{c}-.1373 * * \\
(.0678) \\
328\end{array}$ & $\begin{array}{c}-.0111 \\
(.0626) \\
123\end{array}$ & $\begin{array}{c}-.0372 \\
(.0709) \\
123\end{array}$ & $\begin{array}{c}.0131 \\
(.0619) \\
123\end{array}$ \\
\hline $\begin{array}{l}\text { First Stage } \\
\text { 9-12th : } \alpha_{1}\end{array}$ & $\begin{array}{c}0.9082 \\
(0.7182) \\
923\end{array}$ & $\begin{array}{c}3.4618^{* * *} \\
(1.3274) \\
877\end{array}$ & $\begin{array}{c}3.3375^{* *} \\
(1.4056) \\
792\end{array}$ & $\begin{array}{c}2.2745^{* *} \\
(1.0609) \\
935\end{array}$ & $\begin{array}{c}0.6915 \\
(2.2489) \\
8.53\end{array}$ & $\begin{array}{c}0.9413 \\
(2.2668) \\
7.24\end{array}$ \\
\hline $\begin{array}{c}\text { LIML } \\
\text { 9-12th : } \beta_{1}\end{array}$ & $\begin{array}{c}-0.1312^{* *} \\
(0.0566)\end{array}$ & $\begin{array}{c}-0.1061^{*} \\
(0.0560)\end{array}$ & $\begin{array}{l}-0.1064 \\
(0.0548)\end{array}$ & $\begin{array}{l}-0.0839 \\
(0.0640)\end{array}$ & $\begin{array}{c}-0.1311^{*} \\
(0.0694)\end{array}$ & $\begin{array}{l}-0.0757 \\
(0.0552)\end{array}$ \\
\hline
\end{tabular}


Table A.2. 2SLS Estimates for Dropout Rates (Discontinuity Sample: $\pm 5 \%$ and $\pm 2 \%$, 2003/4 2007/08 School Year)

\begin{tabular}{|c|c|c|c|c|c|c|}
\hline Grade & $\begin{array}{l}\text { IV(5\%) } \\
\text { Coef./se }\end{array}$ & $\begin{array}{c}\text { Linear(5\%) } \\
\text { Coef./se }\end{array}$ & $\begin{array}{c}\text { Linear } \times \\
\text { WIN(5\%) } \\
\text { Coef./se }\end{array}$ & $\begin{array}{l}\text { IV(2\%) } \\
\text { Coef./se }\end{array}$ & $\begin{array}{c}\text { Linear(2\%) } \\
\text { Coef./se }\end{array}$ & $\begin{array}{c}\text { Linear } \times \\
\text { WIN(2\%) } \\
\text { Coef./se }\end{array}$ \\
\hline $\begin{array}{l}\text { 9-12th : } \beta_{1} \\
\text { No. of Obs. }\end{array}$ & $\begin{array}{c}-.1004 \\
(.0768) \\
780\end{array}$ & $\begin{array}{c}-.0930 \\
(.0783) \\
780\end{array}$ & $\begin{array}{c}-.0942 \\
(.0789) \\
780\end{array}$ & $\begin{array}{c}-.0784 \\
(.0794) \\
296\end{array}$ & $\begin{array}{c}-.1624 \\
(.1108) \\
296\end{array}$ & $\begin{array}{c}-.1122 \\
(.1031) \\
296\end{array}$ \\
\hline $\begin{array}{l}\text { First Stage } \\
\text { 9-12th : } \alpha_{1} \\
\text { F-statistic }\end{array}$ & $\begin{array}{c}0.6723^{*} \\
(0.3895) \\
10.24\end{array}$ & $\begin{array}{c}0.9369 \\
(0.7691) \\
9.60\end{array}$ & $\begin{array}{c}0.7832 \\
(0.8025) \\
8.99\end{array}$ & $\begin{array}{c}1.0958^{*} \\
(0.6033) \\
7.04\end{array}$ & $\begin{array}{c}0.1717 \\
(1.3460) \\
6.81\end{array}$ & $\begin{array}{c}0.0754 \\
(1.3565) \\
6.54\end{array}$ \\
\hline
\end{tabular}

